\title{
China's E-Commerce Higher Education: A 15 Years Review from International Viewpoint
}

\author{
Mingxuan Wu${ }^{1}$, Mingming Wang ${ }^{2}$, Jeffrey Soar ${ }^{3}$, Ergun Gide ${ }^{4}$ \\ ${ }^{1}$ Faculty of Engineering and Technology, CQ University, Sydney, Australia \\ ${ }^{2}$ School of Information, Renmin University of China, Beijing, China \\ ${ }^{3}$ Faculty of Business and Informatics, CQ University, Toowoomba, Australia \\ ${ }^{4}$ Faculty of Business, University of Southern Queensland, Sydney, Australia \\ Email: Robert_wumx@hotmail.com,wmingming@ruc.edu.cn,soar@usq.edu.au, e.gide@cqu.edu.au
}

How to cite this paper: $\mathrm{Wu}, \mathrm{M} . \mathrm{X}$., Wang, M.M., Soar, J. and Gide, E. (2016) China's E-Commerce Higher Education: A 15 Years Review from International Viewpoint. Open Journal of Social Sciences, 4, 155-164. http://dx.doi.org/10.4236/jss.2016.410012

Received: September 11, 2016

Accepted: October 25, 2016

Published: October 28, 2016

Copyright $\odot 2016$ by authors and Scientific Research Publishing Inc. This work is licensed under the Creative Commons Attribution International License (CC BY 4.0).

http://creativecommons.org/licenses/by/4.0/

(c) (†) Open Access

\begin{abstract}
China's education sector has involved in e-commerce programs since the beginning of this century as one of international pioneers in 2001. However, a gap still exists between China's e-commerce education and industry demands that China's e-commerce education seems far from meeting business's expectations. This paper described firstly the current situation of China's e-commerce education. Based on the literature review and interviews, the reasons why this gap existed were then analysed with four challenges including argue on separate vs. integrated focus, technical vs. non-technical focus, textbook concerns, and lack of industry involvement. Finally, several suggestions were provided for helping China's educators to gain input from international experience and solving relevant challenges. Although this research focused mainly on China's e-commerce education, the introductory materials discussing China's current state should be valuable for any universities being interested in China's e-commerce education. This can also serve as a spring board to discuss the overall framework for e-commerce education in developing countries.
\end{abstract}

\section{Keywords}

E-Commerce, E-Commerce Education, E-Commerce Program, Higher Education

\section{Introduction}

In the review of literature, research into e-commerce education has been conducted since early 2000. Although many researchers such as Toraskar \& Lee (2006, p. 8) [1] have discussed the basic issues in planning and design of the e-commerce education, educational issues in e-commerce are yet largely unresolved so far (Rezaee, Lambert, and Harmon 2006, p. 74) [2]. They are also challenging China's e-commerce programs. 
China's education sector has involved in e-commerce programs since the beginning of this century as one of international pioneers in 2001. China's educators find that they have to still face number of issues in developing e-commerce programs. The most important issue is that a gap exists between China's e-commerce education and industry demands. It is therefore a need for China's educators to review the current situation of e-commerce programs and refer to international experience so as to select the most appropriate pathway in further development of e-commerce education.

\section{The Current Situation of China's E-Commerce Higher Education}

The current situation of China's e-commerce education might be described briefly through summarizing three features of its development.

First, China's educators offered e-commerce education as one of international pioneers. In literature review, the world's first undergraduate e-commerce program was offered by Acadia University, Canada in September 2000 (Trudel and Trudel, 2004, p. 2) [3] where University of California, San Diego was first to offer Master's Degree in E-commerce in 1998 (Weinstein 1998) [4]. China's universities started to recruit students in bachelor of e-commerce programs in September 2001 (Zhu and Zhao, 2001) [5]. Clearly, China's educators caught up with international steps in e-commerce education early. Table 1 shows other international pioneers in e-commerce education.

Second, there is a substantial trend of increase in China's e-commerce programs. By May 2015, China has established a total of 2553 higher education institutes (EOL 2015) including 796 universities. About $34.42 \%$ of them (274 out of 796) have provided e-commerce programs. This is a substantial increase from the year of $2001(2.18 \%, 13$

Table 1. The international pioneers in e-commerce higher education.

\begin{tabular}{|c|c|c|c|c|}
\hline Year & Country & E-Commerce Program Provider & Program & Reference \\
\hline Jul-98 & USA & $\begin{array}{c}\text { University of California, San } \\
\text { Diego }\end{array}$ & $\begin{array}{c}\text { Master degree program in } \\
\text { e-commerce }\end{array}$ & Weinstein 1998 \\
\hline Jul-99 & UK & $\begin{array}{l}\text { University of Portsmouth } \\
\text { Business School }\end{array}$ & $\begin{array}{l}\text { MA Marketing with } \\
\text { e- commerce }\end{array}$ & M2 Presswire 1999 \\
\hline Jan-00 & USA & $\begin{array}{l}\text { Boston University's } \\
\text { Metropolitan College }\end{array}$ & $\begin{array}{l}\text { Master of science in } \\
\text { e-commerce }\end{array}$ & Godbout 1999 \\
\hline Sep-00 & Canada & Acadia University & $\begin{array}{c}\text { Bachelor of computer science } \\
\text { with a specialisation in } \\
\text { e-commerce }\end{array}$ & $\begin{array}{l}\text { Trudel and Trudel } \\
\qquad 2004\end{array}$ \\
\hline Mar-01 & Australia & Central Queensland University & Master of e-commerce & $\begin{array}{l}\text { CQU Handbook } \\
2001\end{array}$ \\
\hline Oct-01 & UK & $\begin{array}{c}\text { The Management School of } \\
\text { Liverpool University }\end{array}$ & $\begin{array}{l}\text { Undergraduate degree in } \\
\text { e-Business }\end{array}$ & Liv 2001 \\
\hline 2001 & $\begin{array}{l}\text { New } \\
\text { Zealand }\end{array}$ & The University of Waikato & $\begin{array}{l}\text { Undergraduate degree in } \\
\text { e-commerce }\end{array}$ & $\begin{array}{l}\text { Waikato University } \\
2000\end{array}$ \\
\hline
\end{tabular}


out of 597) (see Table 2).

Third, the peak period of China's e-commerce programs was provided between 2006 and 2010 with $42.56 \%$ in 2006 (306 out of 719), 43.67\% in 2007 (324 out of 742), $43.31 \%$ in 2008 (327 out of 755), 44.03\% in 2009 (339 out of 770), 42.80\% in 2010 (339 out of 792).

\section{Review of China's E-Commerce Education}

Although China's education sector has involved in e-commerce programs since the beginning of this century, China's educators find that number of issues still exist in developing e-commerce programs. The most important issue is that a gap exists between China's e-commerce education and industry demands that China's e-commerce education seems far from meeting business's expectations. China's researchers believe, such as Chen, Hu and Wang (2004, p. 70) [6] and Zhang, Li and Lin (2005, p. 9) [7], that China's e-commerce education does not match the industry demands. Many business managers found that it was difficult to find appropriate employees with qualified e-commerce skills (Liang 2006 [8], Liu 2006 [9]), while e-commerce graduates found that it was difficult to get appropriate job positions.

Research showed that e-commerce program was at the lowest employed rate (20\%) of all undergraduate majors (Liu 2006 [9], Zheng 2006 [10]). Based on the literature review

Table 2. A 15 years review of China's e-commerce education.

\begin{tabular}{|c|c|c|c|c|c|}
\hline Year & No. of Programs & Reference & No. of Uni. & Reference & $\%$ \\
\hline 2001 & 13 & (Zhu \& Zhao 2001) & 597 & (EDU 2002) & $2.18 \%$ \\
\hline 2002 & 96 & (Feng \& Ling 2002) & 629 & (EDU 2002a) & $15.26 \%$ \\
\hline 2003 & 153 & (Zhang 2004) & 642 & (EDU 2003) & $23.83 \%$ \\
\hline 2004 & 217 & (Gide and Wu 2005) & 645 & (EDU 2004) & $33.64 \%$ \\
\hline 2005 & 275 & (MOE 2005) & 700 & (EDU 2005) & $39.29 \%$ \\
\hline 2006 & 306 & (Zhang 2007) & 719 & (EOL 2006) & $42.56 \%$ \\
\hline 2007 & 324 & (EC Education Committee 2008) & 742 & (EOL 207) & $43.67 \%$ \\
\hline 2008 & 327 & (Chen 2010) & 755 & (MOE 2008) & $43.31 \%$ \\
\hline 2009 & 339 & (EC Education Committee 2010) & 770 & (Xinhuanet 2009) & $44.03 \%$ \\
\hline 2010 & 339 & BAIDU (n.d.) & 792 & (MOE 2010) & $42.80 \%$ \\
\hline 2011 & 205 & (NSEAC 2012) & 820 & (MOE 2011) & $25.00 \%$ \\
\hline 2012 & 244 & (360doc 2013, NSEAC 2013) & 844 & (MOE 2012) & $28.91 \%$ \\
\hline 2013 & 267 & (NSEAC 2014) & 879 & (MOE 2013) & $30.38 \%$ \\
\hline 2014 & 291 & (66CV 2015) & 776 & (Xinhuanet 2014) & $37.50 \%$ \\
\hline 2015 & 274 & & 796 & (EOL 2015) & $34.42 \%$ \\
\hline
\end{tabular}

(Note: \% stands for no. of programs divided by no. of universities). 
and interviews, the reasons why this gap existed were analysed with four challenges including organisation of e-commerce education, instructor development, textbook concerns, and lack of industry involvement.

\subsection{Argument on Separate vs. Integrated Focus}

In the review of research on e-commerce education, the first perspective of China's e-commerce education is for the debates on whether to keep an e-commerce program separate, or integrate it into information system (IS) program since the e-commerce curriculum evolved as an outgrowth of IS education (Rob 2003, p. 26) [11]. This can be viewed that nearly half of China's universities have provided e-commerce programs in 2009 (see Table 1), while other universities have not considered that it is necessary to offer such programs yet.

Separate focus is to treat e-commerce as a stand-alone discipline, requiring the establishment of a separate degree program in e-commerce (Rezaee, Lambert and Harmon 2006, pp. 76-77) [2]. Sanford (2000) [12] supported that e-commerce should intersect with education as a separate educational topic. In fact, not only early approaches were to create an e-commerce program as a degree major (Moshkovich, Mechitov and Olson 2006, p. 185) [13], but also some universities have provided separate e-commerce programs recently. For examples, nine China's universities have established separate e-commerce faculties/schools/departments in 2015 as follows:

- Wuhan Technology and Business University,

- Henan University of Animal Husbandry and Economy,

- Henan University of Economics and Law,

- Hainan Normal University,

- Guangzhou University,

- Chengdu University of Technology,

- Jilin University of Finance and Economics,

- Huzhou University, and

- Donghua University.

Integrated focus is to infuse e-commerce as topics throughout the business curriculum (Rezaee, Lambert and Harmon, 2006, pp. 76-77) [2]. Edward Snyder, Dean of the University of Virginia's Darden Business School said: "You're missing the point if you set up a separate program..." (Leonhardt, 2000) [14]. Snyder's views have been echoed by many professors and administrators who were convinced that e-commerce should not be considered as a distinct area of study (Durlabhji and Fusilier, 2002, p. 174) [15]. Thus, many universities have incorporated e-commerce education in their existing curricula (Leonhardt, 2000 [14], Kim, Han, Kim and Choi, 2005, p. 56 [16]). E-commerce did not be offered as a separate program in these universities.

\subsection{Technical vs. Non-Technical Focus}

Another perspective is on technical vs. non-technical focus. This has been discussed widely such as Durlabhji and Fusilier (2002, p. 170, 174) [15], Chopoorian and Wang 
(2004, p. 109) [17], Kim, Han, Kim, and Choi (2005, p. 56) [16], Ngai, Gunasekaran, and Harris (2005, p. 7) [18], and Ngai, Lok, Ng, Lo, and Wong (2005, p. 109) [19]. With current e-commerce system requires an e-commerce practician to have a thorough knowledge of both technical and non-technical courses (Kim, Han, Kim, and Choi, 2005, p. 56) [16]. E-commerce graduates need therefore to be taught with a wide range of skills (Dastbaz and Chadwick, 2005 [20], Ngai, Lok, Ng, Lo, and Wong, 2005, p. 110 [19]). Ngai, Gunasekaran and Harris $(2005$, p. 7) [18] found that it was difficult to provide students with a balance of the technical and non-technical aspect of e-commerce.

Technical focus is more on e-commerce technologies' knowledge and skill (Ngai, Gunasekaran and Harris, 2005, p. 6) [18]. They are mainly related to the development and management of e-commerce systems (Kim, Han, Kim, and Choi, 2005, p. 56) [16]. The world's first undergraduate e-commerce program was technically focused (Trudel and Trudel, 2004, p. 256) [3]. In technical focus, many academic units provide the contexts to understand the technology, and its applications such as customer data collection, catalog development, web page design and associated programming languages, linking of databases to the website, telecommunication, networking and other technical concerns (Kim, Han, Kim and Choi, 2005, p. 56) [16]. From the mid-1990s through the present, e-commerce education in the information technology (IT)/IS curriculum has been one of never-ending change, not to mention endless class preparations (Tabor, 2005, p. 19) [21]. Rob (2003, p. 26) [11] highlights that demand exists for the e-commerce programs with technical focus-just as the market demand exists for people with handson experience in the latest technology.

A China's industry survey also indicates that employees with appropriate IS skills are listed at the top of ten requirements that e-commerce graduates must have (Xiong, 2006, p. 7) [22]. Most of China's e-commerce programs however focus on non-technical focus. $17.15 \%$ (47 out of 274 ) of China's e-commerce programs are only technical focus in 2015 (see Table 3).

Business based programs generally focus more on non-technical knowledge and skills (Ngai, Gunasekaran and Harris, 2005, p. 6) [18]. Durlabhji \& Fusilier (2002, p.

Table 3. Structure of programs in 2015.

\begin{tabular}{ccc}
\hline Department & No. & $\%$ \\
\hline Economics & 109 & $39.78 \%$ \\
Management & 55 & $20.07 \%$ \\
IT/IS & 47 & $17.15 \%$ \\
Business & 45 & $16.42 \%$ \\
E-commerce & 9 & $3.28 \%$ \\
Logistics & 6 & $2.19 \%$ \\
Finance & 3 & $1.09 \%$ \\
Sum & 274 & $100.00 \%$
\end{tabular}


170) [15] examine all the programs listed on the web site of the American Association of Colleges and Schools of Business and found that the ratio of total non-technical e-commerce courses to technical e-commerce courses was 2.5 to 1. King, Frank, and Platt (2001, p. 336) [23] reported that the majority (71\%) of courses within e-commerce programs were offered in business school. They frequently focus on the changes in the business and the industry due to e-commerce including the basic concepts of e-commerce, the development of e-commerce, finance, accounting, public policy, leadership, and social engineering, the processes in marketing research, marketing and technology management (Kim, Han, Kim and Choi, 2005, pp. 55-56 [16], Grenci, 2005, p. 44 [24]). They were more related to the training of e-commerce managers (Kim, Han, Kim, and Choi, 2005, p. 56) [16].

\subsection{Textbook Concerns}

The availability of quality textbooks and supplements is a critical issue (Zhang, $\mathrm{Li}$, and Lin, 2005, p. 10 [7], Liang, 2006 [8]). Although many real business practices have been adopted in current textbooks as case studies, it still lacks content of up-to-date e-commerce practices, specially in technical focus, such as PHP programming language.

The frequency of revising textbooks is another issue. Surveys indicate that e-commerce changes rapidly to require e-commerce course contents revised frequently even yearly revision of textbooks (McBride, 2005, p. 75 [25]; Ngai, Lok, Ng, Lo, and Wong, 2005 , p. 115 [19]). Long course development timescales can reduce courses to a catalogue of current applications which may not reflect the overall situation in the market and may be simplified and lack depth in describing content or process (McBride, 2005, p. 75) [25]. It is however difficult to find up-to-date cases and to absorb a constant flow of new e-commerce knowledge and technology into teaching materials (Ngai, Lok, Ng, Lo, and Wong, 2005, p. 115) [19]. Constant re-writing of material also places a burden on the teaching which detracts from developing delivery approaches, teaching the material and carrying out assessment (McBride, 2005, p. 75) [25].

\subsection{Lack of Industry Involvement}

It is obviously that China's e-commerce education is still far from business practices and lacks industry involvement. In recent years, some China's universities have established number of joint programs with industries. However, it is still far from business demands. When professor Manhui Huang-from Department of E-commerce at China's Guangdong University of Business Studies-was interviewed on 4 April 2007, she stated

“...it is necessary to enhance e-commerce students with e-commerce development skills". This was further highlighted by Professor Yanwu Chen at the business school of China's Huaqiao University as: “...specially in developing e-commerce system for a real business project".

The real world of e-commerce itself is however still relatively new so that there is little common understanding and consensus about how businesses themselves should plan and manage the fast changing IT used in e-commerce (Toraskar \& Lee, 2006, p. 9) 
[1]. Thus, it is difficult for universities to run e-commerce programs with practical components (Ngai, Lok, Ng, Lo, and Wong, 2005, p. 114) [19].

\section{Discussions and Suggestions}

Although China's e-commerce education has to face above critical challenges, research forecasts that China's e-commerce education would boom in coming years. Employee with relevant e-commerce skills has become a key element of business successfully adopting e-commerce system. Latest evidence firmly indicates that employing e-commerce staff as well as business managers at different levels with relevant e-commerce knowledge and skills has become one of the critical factors for China's businesses to successfully adopt e-commerce systems (Wu, Rod, Gide, 2012, p. 181) [26].

China's higher education system is however complex compared to the majority of other countries (Wu and $\mathrm{Yu}, 2006, \mathrm{p} .212$ ) [27]. They are classified into thirteen categories including comprehensive, science and arts, science and engineering, liberal arts, science, engineering, agriculture, medical and health science, law, literature, management, sport and arts (CAS, 2002) [28]. They also have obvious difference among a number of academic staff employed, enrolled students, and government finance support. It is impossible for a variety of universities to adopt the same program structure. There is need urgently therefore for china's educators to refer existing international experience so as to select the most appropriate pathway in further developing e-commerce education.

\subsection{Organisation of E-Commerce Education}

It is preferred that universities opt for different e-commerce development strategies and organise their programs.

- Option 1: Establishing a separate e-commerce department within university

There are possibilities for some of China's universities to establish a separate e-commerce department. This recommendation has been supported by Rob (2003, p. 26) [11] that an e-commerce program could not survive without a core faculty taking full responsibility for its upkeep. The main reason is that whether a university is considering adding e-commerce to its curriculum for the first time, or expanding its e-commerce offerings, it should consider a multi-disciplinary approach between its business and computer science departments (Trudel and Trudel, 2004, p. 258) [3]. It is therefore difficult for any traditional schools to run e-commerce programs separately. China's e-commerce educators might establish provide e-commerce programs depend on different university goals individually, such as e-commerce programs in the travel industry, banking industry, and healthcare industry.

- Option 2: Providing an e-commerce program by a business school

It is good option to provide an e-commerce program within existing business schools if establishing a separate e-commerce department is impossible. Celsi and Wolfinbarger (2001, p. 309) [29] highlight that the most logical organisational end-goal of any ecommerce programs is the integration of e-commerce into the general curriculum, with the recognition that ultimately most courses will be revamped to varying degrees to 
match business realities.

In the past, business schools generally considered technology and business strategy as separate functions, as did companies (Celsi and Wolfinbarger, 2001, p. 309) [29]. Today, business schools are well advised to maintain discussions with practitioners as they develop and evolve e-commerce course content (Mitchell and Strauss, 2001, p. 100) [30]. In developing an e-commerce curriculum, however, business schools should consider their program's mission (business strategy, technical aspects); targeted students (traditional/non-traditional training for senior managers); resource availability including a qualified faculty, infrastructure (classroom technologies and smart laboratories); and tailor their e-commerce curriculum design (Rezaee, Lambert, and Harmon, 2006, p. 85) [2]. The Wharton school at the University of Pennsylvania in US provided the MBA in Managing Electronic Commerce degree according to its student resource guide 2007-2008 (Wharton, 2007) [31].

- Option 3: Running an e-commerce program by a IS or IT school

Another option is to provide an e-commerce program within existing IS or IT schools. This can run a computer science based e-commerce program specialisation (Trudel and Trudel, 2004, p. 259) [3]. This kind of e-commerce program might cover the enabling IT infrastructure for e-commerce as well as the latest e-commerce applications (Ngai, Gunasekaran and Harris, 2005, p. 6) [18].

- Option 4: Collaborating an e-commerce program by the IS and business schools

The undergraduate e-commerce program should prepare students to assume responsible positions in a high-tech industry and business environment utilizing advanced technologies (Rezaee, Lambert, and Harmon, 2006, p. 87) [2]. Therefore, collaborating e-commerce programs by IS and business schools should also be considered. This flexibility for schools to accommodate both technical and non-technical specialisations might be the most prudent approach in today's turbulence (Durlabhji and Fusilier, 2002, p. 174) [15].

\subsection{Textbooks and Supplements with Industry Involvement}

The appropriate way of industry involvement is to collaborate with industry in developing e-commerce textbooks and supplements with both industry managers and technical experts. Recommendations from business practitioner can help make e-commerce programs relevant and up-to-date and can ensure graduate marketability and reduce corporate criticism about programs being out of touch with reality (Mitchell and Strauss, 2001, p. 91) [30]. Technical experts can make concerns about the use of the latest e-commerce technology which should be involved in e-commerce education, and how to run an e-commerce project in the best way to fit the needs of the students (Ngai, Lok, Ng, Lo, and Wong, 2005, p. 115) [19]. They can also provide both success and failure real case stories.

\section{Conclusions and Further Research}

China's higher educational institutions are taking steps to keep up with the internationalisation of education while China is embracing the world's economy and markets 
more than ever since entering the 21st century (Wu and $\mathrm{Yu}, 2006, \mathrm{p} .220$ ) [27]. This also includes increasing the availability of China's e-commerce programs.

This research makes a contribution from an international viewpoint into China's e-commerce education with 15-year period review from 2001 to 2015 on China's e-commerce higher programs. The introductory materials discussing China's current state should be valuable for any universities being interested in China's e-commerce education. This can also serve as a spring board to discuss the overall framework for e-commerce education in developing countries.

In further research, there is a need to identify which courses should be taught in e-commerce programs and provide a guideline in how balancing IT and business courses in developing e-commerce programs.

\section{References}

[1] Toraskar, K. and Lee, P.C.B. (2006) A Contextualist Approach to the Development of Ecommerce Education: An Analysis of Key Issues And Challenges. Journal of Information Technology Management, XVII, 1-12.

[2] Rezaee, Z., Lambert, K.R. and Harmon, W.K. (2006) Electronic Commerce Education: Analysis of Existing Courses. Accounting Education: An International Journal, 15, 73-88. http://dx.doi.org/10.1080/06939280600579370

[3] Trudel, C. and Trudel, A. (2004) World's First Undergraduate E-Commerce Specialization Offered by a Computer Science Department. Journal of Computing Sciences in Colleges, 20, 254-259.

[4] Weinstein, B. (1998) Calif. University Is First to Offer Master's Degree in E-commerce. May 31, Boston Globe.

[5] Zhu, Q. and Zhao, W. (2001) 13 Universities Have Been Approved to Run Bachelor of E-Commerce Programs. (In Chinese)

[6] Chen, J.H., Hu, Y. and Wang, W. (2004) E-commerce Education in China. Journal of Electronic Commerce in Organizations, 2, 65-77. http://dx.doi.org/10.4018/jeco.2004040106

[7] Zhang, X.F., Li, Q. and Lin, Z.X. (2005) E-Commerce Education in China: Driving Forces, Status, and Strategies. Journal of Electronic Commerce in Organizations, 3, 1-17. http://dx.doi.org/10.4018/jeco.2005070101

[8] Liang, X.C. (2006) Contradiction, Reconsideration and Suggestion for China's E-commerce Higher Education. (In Chinese)

[9] Liu, X.Y. (2006) The Lack of People with E-commerce Skills: From Network Bottleneck to Human Resource Bottleneck. (In Chinese) http://www.ce.cn/cysc/tech/gnhlw/200611/28/t20061128_9606054.shtml

[10] Zheng, P. (2006) Review of China's E-commerce Education. (In Chinese) http://news.xinhuanet.com/ec/2005-06/03/content_3039822.htm

[11] Rob, M. (2003) The Rise and Fall of an E-commerce Program. Communications of the $A C M, 46,25-26$. http://dx.doi.org/10.1145/636772.636790

[12] Sanford S. (2000) E-Commerce and Education: Pressure, Progress and Innovation.

[13] Moshkovich, H.M., Mechitov, A.I. and Olson, D.L. (2006) E-Commerce and the Undergraduate MIS Curricula: an Exploratory Study. Journal of Information Systems Education, 17, 185-194.

[14] Leonhardt, D. (2000) Business; at Graduate Schools, a Great Divide over E-Business Stu- 
dies. The New York Times, Jan 16.

[15] Durlabhji, S. and Fusilier, M.R. (2002) Ferment in Business Education: E-commerce Master's Programs. Journal of Education for Business, 27, 169-176. http://dx.doi.org/10.1080/08832320209599067

[16] Kim, H., Han, Y., Kim, S. and Choi, M. (2005) A Curriculum Design for E-commerce Security. Journal of Information Systems Education, 16, 55-64.

[17] Chopoorian, J. and Wang, S. (2004) A Technical Module for the E-Commerce Course. Journal of Information Systems Education, 15, 109-111.

[18] Ngai, E.W.T., Gunasekaran, A. and Harris, A. (2005) The Maturing of E-Commerce Education in Our Curricula. Journal of Information Systems Education, 16, 5-8.

[19] Ngai, E.W.T., Lok, C.K., Ng, E.M.W., Lo, C.N. and Wong, Y.K. (2005) Collaborative Project across Three Hong Kong Universities: A Case Study in E-commerce Education. Journal of Information Systems Education, 16, 109-116.

[20] Dastbaz, M. and Chadwick, D. (2005) E-business and Higher Education: An Exercise in Marketing or Fulfilling Academic Need?

[21] Tabor, S.W. (2005) Achieving Significant Learning in E-Commerce Education through Small Business Consulting Projects. Journal of Information Systems Education, 16, 19-26.

[22] Xiong, L. (2006) The Business Demands and E-commerce Education. (In Chinese)

[23] King, C.G., Frank, S.L. and Platt, R.G. (2001) E-Commerce Courses: Overview of Nature and Content. Journal of Education for Business, 76, 332-337.

http://dx.doi.org/10.1080/08832320109599658

[24] Grenci, R.T. (2005) Framing Electronic Commerce within an Introductory Information Systems Course. Journal of Information Systems Education, 16, 43-54.

[25] McBride, N.K. (2005) A Student-Driven Approach to Teaching E-Commerce. Journal of Information Systems Education, 16, 75-83.

[26] Wu M.X., Jewell, R. and Gide, E. (2012) An Eyeball Diagram: Illustrating the Common CSFs in E-Commerce Business Satisfaction for Successful Adoption of E-Commerce Systems by SMEs. International Journal of Electronic Customer Relationship Management, 6, 169-192. http://dx.doi.org/10.1504/IJECRM.2012.048711

[27] Wu, M.X. and Yu, P. (2006) Challenges and Opportunities Facing Australian Universities Caused by the Internationalisation of Chinese Higher Education. International Education Journal, 7, 211-221. Australia. Reprinted by ICFAI Journal of Higher Education, India, Feb 2007 (with Permission of International Education Journal).

[28] CAS (2002) Research on Classifying Chinese Higher Education Institute: Chinese Scholars Provide New Standard. Chinese Academy of Sciences, 26 November 2002.

[29] Celsi, R. and Wolfinbarger, M. (2001) Creating Renaissance Employees in an Era of Convergence between Information Technology and Business Strategy: A Proposal for Business Schools. Journal of Education for Business, 76, 308-312. http://dx.doi.org/10.1080/08832320109599654

[30] Mitchell, T. and Strauss, J. (2001) Practitioner and Academic Recommendations for Internet Marketing and E-Commerce Curricula. Journal of Marketing Education, 23, 91-102. http://dx.doi.org/10.1177/0273475301232003

[31] Wharton (2007) MBA Resource Guide 2007-2008: Managing Electronic Commerce. 
Submit or recommend next manuscript to SCIRP and we will provide best service for you:

Accepting pre-submission inquiries through Email, Facebook, LinkedIn, Twitter, etc. A wide selection of journals (inclusive of 9 subjects, more than 200 journals)

Providing 24-hour high-quality service

User-friendly online submission system

Fair and swift peer-review system

Efficient typesetting and proofreading procedure

Display of the result of downloads and visits, as well as the number of cited articles

Maximum dissemination of your research work

Submit your manuscript at: http://papersubmission.scirp.org/

Or contact jss@scirp.org 